\title{
Prophecies and Ruins: Architectural Sources for Leonardo's Adoration of the Magi
}

Emanuela Ferretti, University of Florence, Italy

AS IS WELL KNOWN, Leonardo da Vinci (1452-1519) began his career working in the bottega of Andrea del Verrocchio. Initially, Leonardo collaborated on some of Verrocchio's paintings, but he gradually realized that he was no longer satisfied by working on artworks that were not his own. Three paintings and one commission by the Repubblica (never made) attest to his autonomy in this first Florentine period: the Annunciation (1472-75), the Portrait of Ginevra dei Benci (1474-78), the Adoration of the Magi (1481-82), and the altarpiece commissioned for the Cappella dei Priori in Palazzo Vecchio (1478). The patrons of Leonardo's early paintings may have belonged to different social classes, but they were often linked via bonds of kinship and friendship, partly still to be detailed. For the Priori's commission and for the Adoration of the Magi, numerous elements indicate a "high-level" network that helped to shape the painter's career. Such a network provided him with elements of humanistic and antiquarian culture that were available in the environment fostered by Lorenzo de' Medici.

This article analyzes the Adoration of the Magi from the specific point of view of the history of architecture, adding to the new evidence brought to light from the restoration of the painting at the Opificio delle Pietre Dure, under the direction of Marco Ciatti and Cecilia Frosinini. I will argue that this focus on architecture

Contact Emanuela Ferretti at the University of Florence (emanuela.ferretti@unifi.it).

I would like to thank Mario Bevilacqua, Eliana Carrara, Cecilia Frosinini, Robert Gaston, Nicoletta Marcelli, and Michael Waters for their comments and help. I offer my deepest appreciation to Helen Spande, who translated my article text as well as provided any otherwise unattributed translations from Italian into English throughout. I am also grateful to Jane Tylus and to the two ITS readers for their helpful suggestions.

I Tatti Studies in the Italian Renaissance, volume 23, number 2. ( 2020 by Villa I Tatti: The Harvard University Center for Italian Renaissance Studies. All rights reserved. 0393-5949/2020/2302-0004\$10.00 


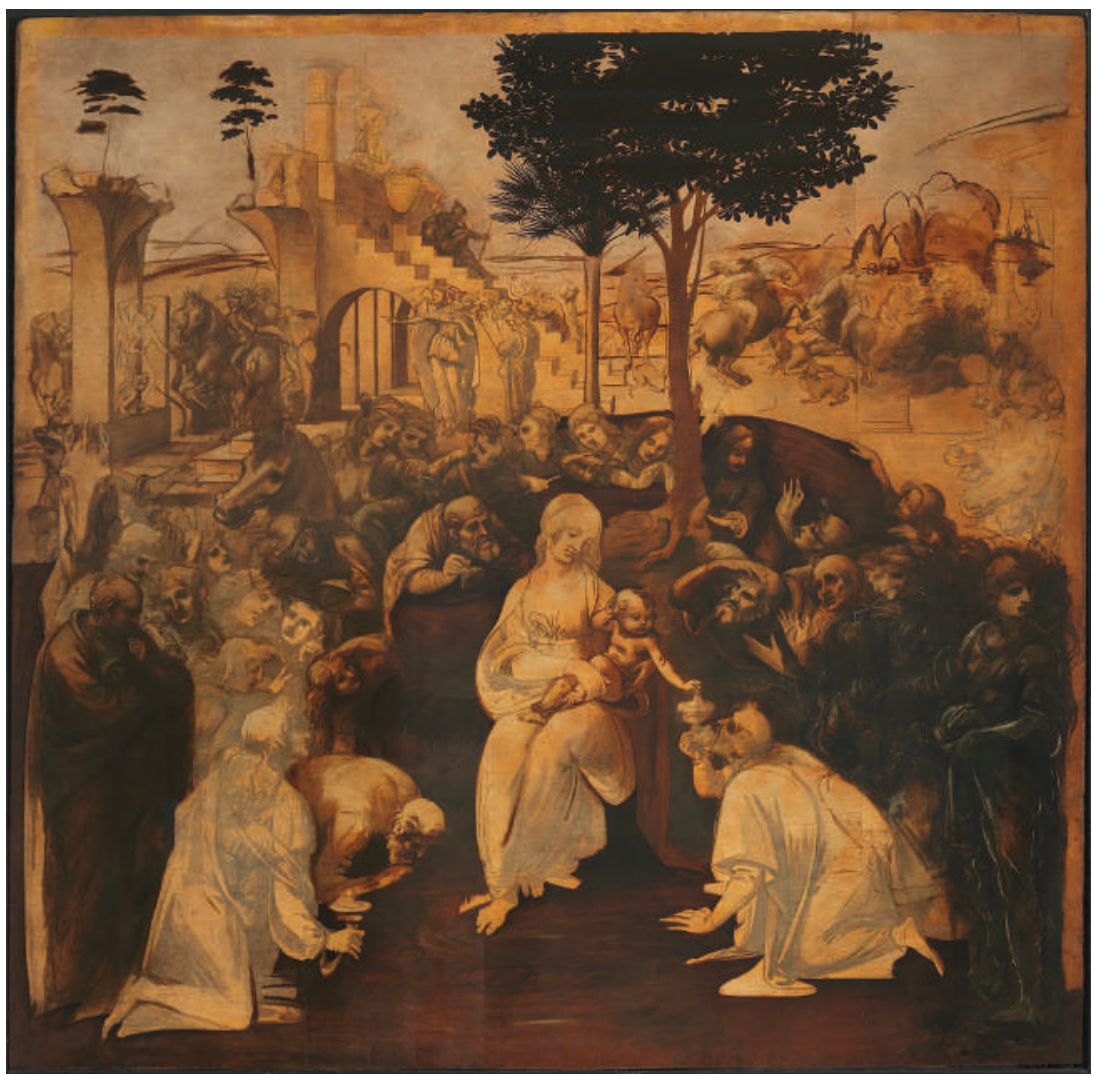

Figure 1. Leonardo da Vinci, Adoration of the Magi, 1481. Oil on wood. (Galleria degli Uffizi, Florence.)

may be useful in clarifying the iconography of Leonardo's Adoration. In what follows, I propose two different interpretations for the meaning of the ruined building in the painting, the structure with arcades and the perpendicular staircases that fills the upper left quadrant of the scene. As the remainder of this article suggests, the building could be either an ancient Roman monument or the Temple of Solomon (fig. 1). Both of these interpretations are plausible and fit with our present state of knowledge. The identification of the type of the building in the Adoration could also help to support the identity (and the cultural profile) of Leonardo's patron for this painting, which was commissioned for the high altar at the Augustinian Church of San Donato a Scopeto. In fact, reconstructing the choices made by the patron might offer scholars new elements for understanding other aspects of the iconography of the painting and its intended religious message. This discussion develops ideas previously encountered in the study of this building in the Adoration 
as well as from research into Leonardo's use of architecture, beginning with the cataloguing of architectural drawings of the artist in the E-Leo Archivio digitale di storia della scienze e tecnica project. ${ }^{1}$

Demonstrating a notable rhetorical bent, Pierre Francastel (1900-1970) observed that "Renaissance architecture was painted before it was built." 2 The many studies of Italian and Florentine architectural history have hardly lessened the worth of this observation on the interaction between painting and architecture in the early Renaissance and beyond. There are, in fact, architectural backgrounds in fresco and easel painting (as well as in intarsia, relief sculpture, gold work, and textiles) that show formal innovations drawn from the seminal works of Filippo Brunelleschi. In a daring game of mirrors between real and virtual architecture, these depictions become in turn a place for experimentation. An interest in rendering architecture and the urban environment in the visual arts was thus consolidated in a tangible way that marked Florentine artistic culture from Giotto onward, plotting a course that served as a starting point for Brunelleschi's research on the rules of perspective and the subsequent theorizing of Leon Battista Alberti. ${ }^{3}$

In general terms, analyzing the nature of painted architecture closely means, on the one hand, delving into the environment and interests of the painter, while on the other, examining iconographical choices. ${ }^{4}$ In the cultural and chronological

1. Emanuela Ferretti, "L'architettura nell'Adorazione dei Magi di Leonardo da Vinci tra morfologia, fenomenologia e gerarchizzazione dello spazio. Alcune considerazioni," 43-56, and "Un arcipelago di simboli e memorie: Tradizione e innovazione nel fondale architettonico dell'Adorazione dei Magi di Leonardo," 151-60, both in Il restauro dell' "Adorazione dei Magi" di Leonardo: La riscoperta di un capolavoro, ed. Marco Ciatti and Cecilia Frosinini (Florence, 2017). For the database of Leonardo's drawings, see https://www.leonardodigitale.com.

2. Pierre Francastel, "L'architecture de la Renaissance a été peinte avant d'être construite," in Peinture et Société: Naissance et destruction d'un espace plastique; De la Renaissance au Cubisme (Lyon, 1951), 70 .

3. See John White, The Birth and Rebirth of Pictorial Space (London, 1957), 113-34; Filippo Camerota, "Introduzione," in Nel segno di Masaccio: L'invenzione della prospettiva, ed. Filippo Camerota, exhibition catalog (Florence, 2001), xiii-xix, at xvi. The vast bibliography includes Francesco Paolo Di Teodoro, “'Che pare sia bucato quel muro': L'architettura 'verosimile' della Trinità di Masaccio," in La festa delle arti: Scritti in onore di Marcello Fagiolo per cinquant'anni di studi, ed. Vincenzo Cazzato, Sebastiano Roberto, and Mario Bevilacqua (Rome, 2014), 1:206-11; Sabine Frommel, “Architectura picta," 11-19; Francesco Benelli, "L'architettura dipinta nella Toscana medievale," 21-41; Christoph L. Frommel, "L'architectura picta da Giotto a Raffaello," 69-98, all in Architectura picta nell'arte italiana da Giotto a Veronese, ed. Sabine Frommel and Gerhard Wolf (Bologna, 2016). Other significant observations are in Sylvia Ferino Pagden, "Architettura dipinta," in Rinascimento da Brunelleschi a Michelangelo, ed. Henry Millon and Vittorio Magnago Lampugnani, exhibition catalog (Venice, 1996), 446.

4. On the environment and interests of the painter, see Stefano Ray, "L'arte naturale e la gentilezza con essa, non uscendo dalle misure': Costruzione e concezione dello spazio in Ghiberti," in Lorenzo Ghiberti nel suo tempo, atti del convegno internazionale di studi (Firenze 18-21 ottobre 1978), 2 vols. (Florence, 1980), 2:483-502, 485-86; Massimo Bulgarelli and Matteo Ceriana, "L'architettura e I Della Robbia," in I Della Robbia: Il dialogo tra le arti nel Rinascimento, ed. Giancarlo Gentilini, exhibition 
contexts of Leonardo da Vinci's Adoration of the Magi, the exchange between architecture and painting was, by the 1480s, an established process. It is in just that freedom of the figurative dimension that such scenes are populated with architectonic structures of a classical mold. ${ }^{5}$ In this exchange, some constants can be discerned: exemplars from the lessons of Lorenzo Ghiberti and Donatello; an expressiveness that draws freely from the architecture of Brunelleschi and his followers to create an original "Florentine way" to classicism, shaped by the defining presence of the local Romanesque legacy; the bonds that the humanists built between art and architecture; and the role of Alberti's theory of architecture in the Laurentian milieu. $^{6}$

One common denominator among many works of art was the inclusion of classical elements in the backgrounds, often for more than cultural or aesthetic purposes. The application of geometric principles for representing space and dimensions was facilitated by the proportions of the architectural orders, and the rationality of classical monuments favors the perception of perspective space in a realistic sense, especially when following the methods theorized by Alberti and Piero della Francesca. ${ }^{7}$ The communicative power of a painting was strengthened through

catalog (Milan, 2009), 137-44; the theme appears indirectly in Filippo Camerota, Francesco Paolo Di Teodoro, and Luigi Grasselli, eds., Piero della Francesca: Il disegno tra arte e scienza, exhibition catalog (Milan, 2015). For the approach of examining iconographical choices, see Francastel, Peinture, 71; Massimo Bulgarelli, "L'architettura nelle tavole prospettiche," in La città ideale: L'utopia del Rinascimento a Urbino tra Piero della Francesca e Raffaello, ed. Alessandro Marchi and Maria Rosaria Valazzi, exhibition catalog (Milan, 2012), 64-81.

5. Arnaldo Bruschi, "Brunelleschi e la nuova architettura fiorentina," in Storia dell'architettura italiana: Il Quattrocento, ed. Francesco Paolo Fiore (Milan, 1998), 84-106; Matteo Ceriana, "Fra Carnevale e la pratica dell'architettura," in Fra Carnevale: Un artista rinascimentale da Filippo Lippi a Piero della Francesca, ed. Matteo Ceriana and Keith Christiansen, exhibition catalog (Milan, 2004), 97-136.

6. On the "Florentine way," see Gabriele Morolli, Firenze e il classicismo: Un rapporto difficile (Florence, 1988), 81. We are faced with a kind of ante litteram eclecticism that has echoes in the architecture of Giuliano da Sangallo or that of Giuliano da Maiano. The all'antica approach was still in Brunelleschian ascendency and thus was differentiated from Alberti's legacy, reflecting a fervent passion for varietas and decorative exuberance tied to a literary vision and evocative of the classical world. See Riccardo Pacciani, "Firenze nella seconda metà del secolo," in Fiore, Storia dell'architettura italiana, 330-72. On the role of Alberti's theory, see Giovanni Agosti, Vincenzo Farinella, and Salvatore Settis, "Passione e gusto per l'antico nei pittori italiani del Quattrocento," Annali della Scuola Normale Superiore di Pisa: Classe di Lettere e Filosofia 17, no. 4 (1987): 1061-107. The idea that Alberti represents an inescapable conceptual landmark is evident in his efforts dedicated to the creation of the editio princeps of the De re aedificatoria, on the initiative of Bernardo Alberti and with the involvement of Lorenzo di Pier Francesco dei Medici. Lorenzo il Magnifico would support the project as well. See Mario Martelli, Studi laurenziani (Florence, 1965), 191 n. 52; Concetta Bianca, "Le dediche a Lorenzo de' Medici nell'Editoria fiorentina," in Laurentia Laurus per Mario Martelli, ed. Francesco Bausi and Vincenzo Fera (Messina, 2004), 51-89, 57.

7. Leonardo Benevolo, Storia dell'architettura del Rinascimento (1973; repr., Milan, 1988), 56; Francastel, Peinture, 66. On this last issue, see Emanuela Ferretti, "Schede VI1a-VI3a," in Camerota, Di Teodoro, and Grasselli, Piero della Francesca, 357-59, and bibliography. 
the use of ancient structures (traditionally associated with specific iconographic subjects) that offered artists an occasion to show their protoarchaeological knowledge. These monuments in turn echoed the interests of patrons and translated the instructions of the literati into the figurative dimension of Laurentian Florence. ${ }^{8}$ It is relevant to note that in 1480-81, Poliziano lectured in the Florentine Platonic Academy on the Silvae of Statius, a work rediscovered by Poggio Bracciolini and published in Venice in 1475 by Domizio Calderini. ${ }^{9}$ Among the various themes that Poliziano took up was the evocative power of ekphrasis and its particular uses in relation to the rediscovery of an antique villa or to re-creating aspects of craftsmanship of a building site (even acoustic aspects of the building). ${ }^{10}$ In $1481-$ 82, Poliziano would dedicate his second course to the commentary of the Fasti of Ovid. ${ }^{11}$ This was the beginning of Poliziano's specific interest in monuments in the city of the Caesars, punctuated by visits and studies of ancient sources, including Vitruvius and Frontinus. ${ }^{12}$ For religious art of the period, incorporating classical motifs would have significance in some works more than others-such as the Adorations, the Martyrdom of Saint Sebastian (fig. 2), or certain episodes in the life of the Virgin.

Even while exercising due caution, one cannot ignore the larger cultural and intellectual contexts that shaped the activity of the young Leonardo. ${ }^{13}$ Nor should one dismiss out of hand the claims of the Anonimo Gaddiano about the presence of the artist in the Garden of San Marco, Lorenzo de' Medici's sculpture garden where Florentine artists gained access to ancient works and compared themselves

8. Agosti, Farinella, and Settis, "Passione e gusto per l'antico," 1065-66.

9. Domizio Calderini, Silvarum Statii Papinii libros quinque a se emendatos (Venice, 1475); Angelo Poliziano, Commento inedito alle "Selve" di Stazio, ed. Lucia Cesarini Martinelli (Florence, 1978).

10. Yvonne Elet, Architectural Invention in Renaissance Rome: Artists, Humanists, and the Planning of Raphael's Villa Madama (Cambridge, 2017), 50, 182, 202 n. 9.

11. Angelo Poliziano, Commento inedito ai "Fasti" di Ovidio, ed. Francesco Lo Monaco (Florence, 1991); Vittore Branca, Poliziano e l'umanesimo della parola (Turin, 1983), 78-83; Lucia Cesarini Martinelli, "Poliziano professore allo Studio fiorentino," in La Toscana al tempo di Lorenzo il Magnifico: Politica economia cultura arte, Atti del convegno internazionale di studi (Firenze-Pisa-Siena, 5-8 novembre 1992) (Pisa, 1996), 2:463-81.

12. Vladimír Juren, "Politien et Vitruve (Note sur le MS. lat. 7382 de la Bibliothèque Nationale)," Rinascimento 18 (1978): 285-92, 292; Jean-Marc Mandosio, “Filosofia, arti e scienze: L'enciclopedismo di Angelo Poliziano," in Poliziano nel suo tempo, ed. Luisa Secchi Tarugi (Florence, 1996), 135-64.

13. Dionisotti warned against claiming Leonardo's direct participation in the Laurentian and humanistic milieu: Carlo Dionisotti, "Leonardo uomo di lettere," in Appunti di arte e lettere (Milan, 1995), 21-50, 37 (essay originally published in Italia Medioevale e Umanistica 5 [1962]: 183-216). For the interactions between the young Leonardo and the court of Lorenzo, as can be seen in the Italian literary production of Pulci and Poliziano, see Giuseppina Fumagalli, Leonardo ieri e oggi (Pisa, 1959), 93-145; Severa Orlando, "Gli interessi linguistici di Leonardo da Vinci," in Interrogativi dell'Umanesimo (Florence, 1976), 91-105; Pulci's work, in particular, was known to Leonardo, and there are traces of it in his manuscripts. See Martin Kemp, Lezioni dell'occhio: Leonardo da Vinci discepolo dell'esperienza (Milan, 2004), 169. 


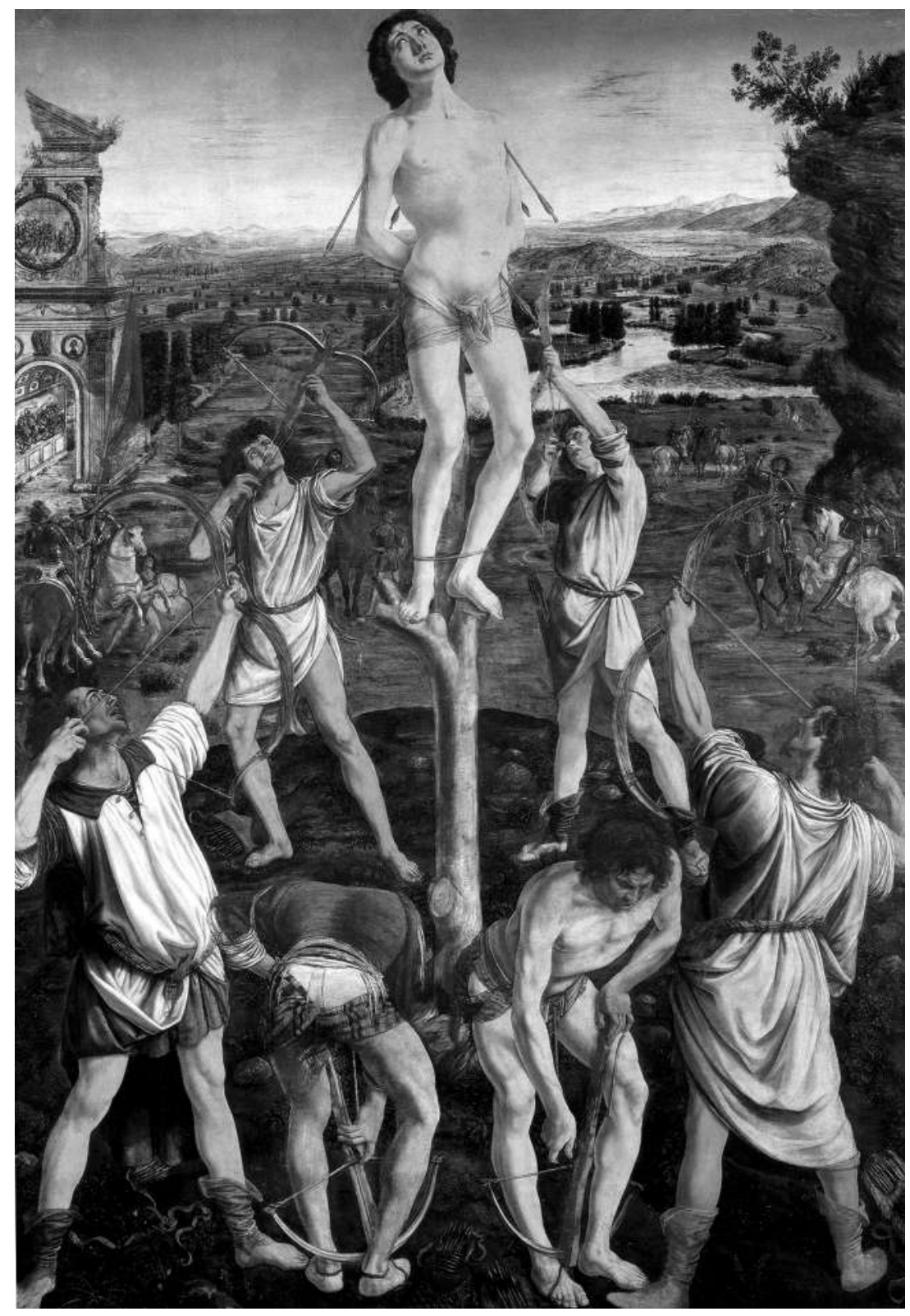

Figure 2. Antonio del Pollaiuolo and Piero del Pollaiuolo, Martyrdom of Saint Sebastian, completed 1475. Oil on canvas. (National Gallery, London.) Color version available as an online enhancement. 
to the Medicean literati. ${ }^{14}$ Classical writings, inaccessible to most artists because of their ignorance of Latin, could become available in other ways, thanks to the mediation of patrons and humanist scholars.

With this background in mind, let us return to Leonardo's Adoration (fig. 1). The crucial rule that architecture plays, both as an instrument for organizing the composition and as an element carrying iconographic meaning, still remains to be completely clarified. The organization of the scene effects a contrast between the monumental structure in ruins and the humble shed of the Nativity, reinterpreting an iconographical theme that was widespread at the time. ${ }^{15}$ We can also observe the central role given to natural elements-such as the architectural form of the rocky exedra (fig. 3) - and a deliberate abstractness that characterizes the building, stripped of ornaments. ${ }^{16}$ These are aspects that show a close relationship, respectively, with the expressivity of Ghiberti and Donatello and, in part, Francesco di Giorgio. ${ }^{17}$ As Arnaldo Bruschi and others maintain, the virtual architecture

14. Caroline Elam, "Il giardino delle sculture di Lorenzo," in Il Giardino di San Marco: Maestri e compagni del giovane Michelangelo, ed. Paola Barocchi, exhibition catalog (Cinisello Balsamo, 1992), 169-70, and “Lorenzo de' Medici's Sculpture Garden," Mitteilungen des Kunsthistorischen Institutes in Florenz 36 (1992): 1-2, 41-84. Also, we can reconsider Enrico Barfucci, Lorenzo de’ Medici e la società artistica del suo tempo, rev. ed. by Luisa Becherucci (Florence, 1964), 188-89; Cecilia Frosinini, "L’Adorazione dei Magi e i luoghi di Leonardo," 23-50; Eliana Carrara, "Spunti per una rilettura delle biografie leonardiane," 51-62, both in Ciatti and Frosinini, Il restauro dell' "Adorazione dei Magi." For Leonardo's studies of ancient art (but not architecture) in his youth, see Michael W. Kwakkelstein, "The Young Leonardo and the Antique," in Aux Quatre Vents: A Festschrift for Bert W. Meijer, ed. Anton W. A. Boschloo, Edward Grasman, and Gert Jan van der Sman (Florence, 2002), 25-32; Pietro C. Marani, “'Imita quanto puoi li Greci e Latini': Leonardo da Vinci e l'antico," in Leonardiana: Studi e saggi su Leonardo da Vinci (Milan, 2010), 169-78.

15. Andrew Hui, "The Birth of Ruins in Quattrocento Adoration Paintings," I Tatti Studies 18, no. 2 (2015): 319-39; Sabine Frommel, "An welchem Ort huldigt man dem neugeborenen Christus? Leonardos Anbetung von San Donato in Scopeto unter dem Zeichen des produktiven Widerspruchs zwischen christlicher Tradition und Antikenrezeption," Acta Historiae Artium Academiae Scientiarum Hungaricae 57 (2016): 83-104.

16. The figure of the Messiah in the sacred scriptures is often associated with the word "stone." In the vision of Daniel, e.g., a stone is cut out of a mountain and becomes, in turn, an immense mountain "that fills all the earth" (book of Daniel 2:24-35). In the Adoration, Leonardo delineates a sort of lithic niche suggesting the archetype of the more usual architectural niche, which frames the figure of the Madonna and Child, seated on a rock surrounded by water, made visible by a recent restoration. For the presence of water at the feet of the Virgin, see Cecilia Frosinini, "L'Adorazione dei Magi di Leonardo da Vinci: Recupero dell'immagine," in Leonardo da Vinci: Metodi e tecniche per la costruzione della conoscenza, atti del convegno, ed. Pietro C. Marani and Rodolfo Maffeis (Busto Arsizio, 2016), 83-91. The representation of abstract solidity seems to anticipate the subsequent interest of the artist in architecture analyzed through statics and the science of construction; Francesco Paolo Di Teodoro and Luciano Barbi, "Leonardo da Vinci: 'Del riparo a' terremoti,'” Physis 25, no. 1 (1983): 5-39.

17. The relationship between Donatello and Francesco di Giorgio is discussed in Howard Burns, “'Restaurator delle ruyne antiche': Tradizione e studio dell'antico nelle attività di Francesco di Giorgio," in Francesco di Giorgio architetto, ed. Francesco Paolo Fiore and Manfredo Tafuri, exhibition catalog, extended version (Milan, 1995), 151-81, 157. 


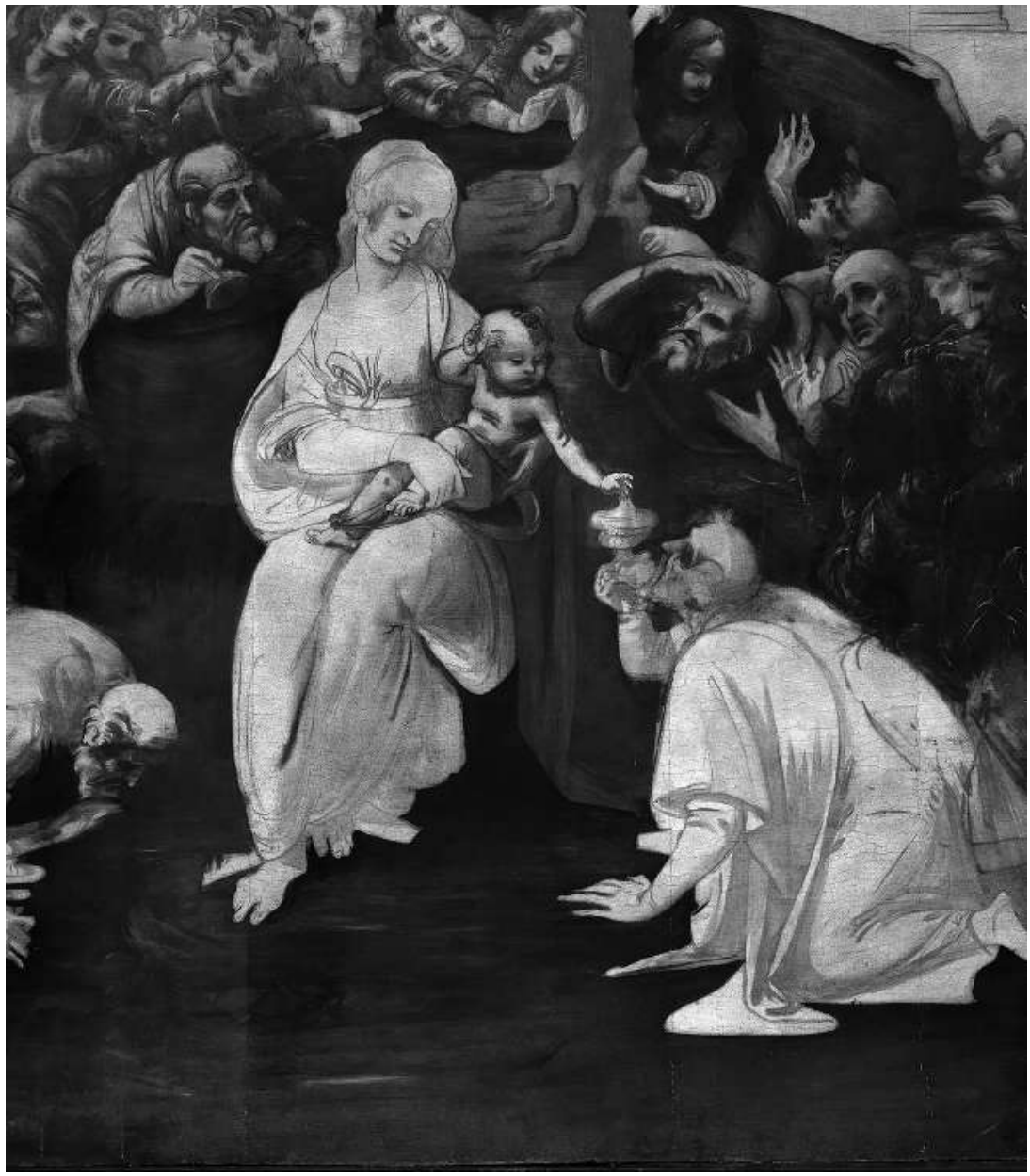

Figure 3. Detail with the Madonna and Child from Leonardo da Vinci, Adoration of the Magi, 1481. Oil on wood. (Galleria degli Uffizi, Florence.) Color version available as an online enhancement.

of the two Florentine sculptors, along with Alberti's ideas on architecture, exerted a strong influence on the morphology of the perspectival spaces created by artists who were their contemporaries as well as by the following generation. ${ }^{18}$ In general terms, in the panels of the Doors of Paradise, Ghiberti appeared more interested in rendering the monumentality of buildings than citing any single arrangement of

18. Arnaldo Bruschi, "Alberti e non Alberti: La cultura 'albertiana' nelle architetture rappresentate in pitture e rilievi nel Quattrocento," in Leon Battista Alberti e l'architettura, ed. Massimo Bulgarelli et al., exhibition catalog (Milan, 2006), 32-63; Diane Cole Ahl, "Captured by the Sight of Such Wonders: Renaissance Painters and the Gates of Paradise," in The Historian's Eye: Essays on Italian Art in Honor of Andrew Ladis, ed. Hayden Maginnis and Shelley Zuraw (Athens, GA, 2009), 113-21. 
specific all'antica elements. ${ }^{19}$ For Ghiberti, re-creating architecture of classical ascendancy was complementary to a specific interest in the mimetic representation of nature, as it would be for Leonardo. Donatello, for his part, was the creator of an architecture animated by a bolder, symmetrical simplicity. ${ }^{20}$ Differences of elevation are often used by Donatello as a means to articulate the scene in a narrative sense, an expedient that would be reused by the artists of the next generation, first and foremost by Leonardo and by the young Michelangelo of the Madonna of the Stairs. ${ }^{21}$ In Donatello's Feast of Herod (fig. 4), for example, the scene is organized by an arcade with simple piers. In the relief, the composition on the left is completed by the column with the palmette capital that sustains a fragment of entablature, an element conceptually close to what appears in the preparatory drawing of the $\mathrm{Ad}$ oration in the Gabinetto Disegni e Stampe degli Uffizi (GDSU; fig. 5). ${ }^{22}$ Ghiberti and Donatello seem to offer Leonardo a variety of solutions for defining aspects of the composition, particularly for the dominant structure and the natural elements. ${ }^{23}$ These influences can be seen, for example, in the more sculptural rendering of the rocks and vegetation (from Ghiberti) and a simplification of the classical architecture (from Donatello).

In earlier work, I addressed the symbolic aspects inherent in the architecture of the Adoration, along with a pointed Vitruvianism in the preparatory drawing of the Louvre, where we can recognize the myth of the humble hut as a sign of the birth of civilization (Vitruvius, De architectura, bk. II, 1, 3) and the wooden origin of the Doric entablature (Vitruvius, De architectura, bk. IV, 2, 2). ${ }^{24}$ For the rest of this article, I intend to present some further observations that will allow for a more precise identification of the large ruined structure in the painting.

To begin with, the comparison that has been proposed between the Adoration's ruined monument and the presbytery of the church of San Miniato al Monte does

19. Richard Krautheimer, "Ghiberti architetto," Bulletin of the Allen Memorial Art Museum 12 (1955): 48-67; Gabriele Morolli, "L'architettura: Dall'Antico all'Utopia," in Lorenzo Ghiberti: "Materia e ragionamenti," exhibition catalog (Florence, 1978), 503-8, and "L'architettura dai Commentari," in Lorenzo Ghiberti nel suo tempo, 2:589-619.

20. The structures and ornaments functioning to unite the scene are traced out with lively sensitivity and reflect the sculptor's plasticity, with a clear debt to the lessons of Leon Battista Alberti: Gabriele Morolli, "Donatello e Alberti 'amicissimi': Suggestioni e suggerimenti albertiani nelle immagini architettoniche dei rilievi donatelliani," in Donatello Studien (Munich, 1989), 43-67; White, Birth and Rebirth, 148-69.

21. See Charles de Tolnay, "Donatello e Michelangelo," in Donatello e il suo tempo: Atti del convegno (Firenze-Padova, 25 settembre-1 ottobre 1966) (Florence, 1968), 259-75.

22. Ferretti, "Un arcipelago di simboli," 151-60.

23. For Leonardo's references to other contemporary paintings with the same subject, see Frosinini, "L'Adorazione dei Magi e i luoghi di Leonardo," 30-33.

24. Ferretti, "L'architettura nell'Adorazione dei Magi," 43-56. 


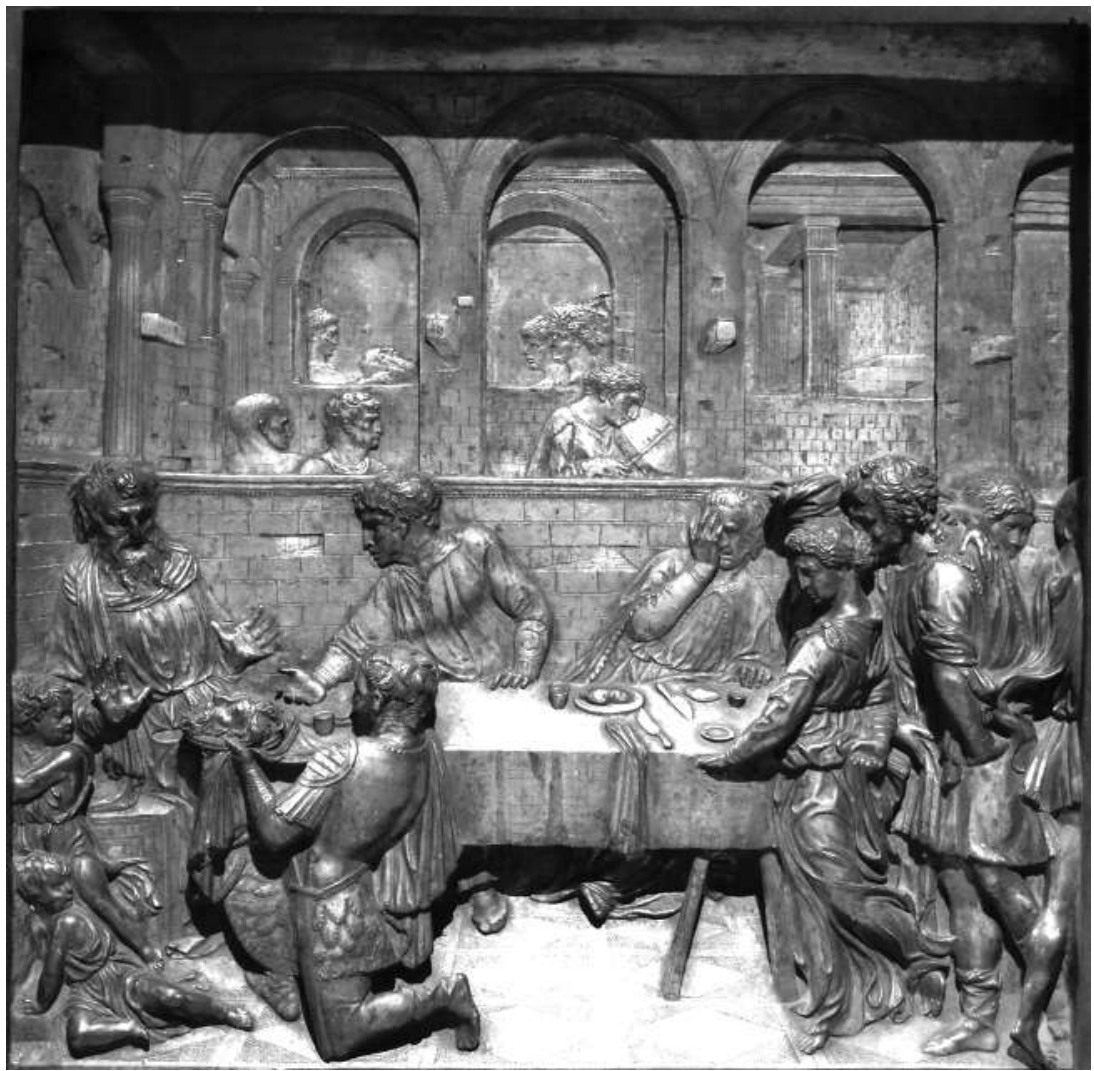

Figure 4. Donatello, Feast of Herod, 1423-27. Bronze relief sculpture. (Baptistery, Siena.) Color version available as an online enhancement.

not seem altogether relevant, nor has its citation in the painting been explained. ${ }^{25}$ Neither does a direct link to the Medici villa at Poggio a Caiano seem fully convincing. Lorenzo de' Medici commissioned the architect Giuliano da Sangallo to build this villa situated in the countryside between Florence and Prato. Before its nineteenth-century modifications, it had two staircases perpendicular to the facade, as does the structure in the Adoration. This has led scholars to deduce a relationship between the villa and the building in Leonardo's painting. ${ }^{26}$ Recently,

25. Antonio Natali, "La predizione di Isaia: Una trama per l'Adorazione dei Magi di Leonardo," in Il cosmo magico di Leonardo: L'Adorazione dei Magi restaurata, exhibition catalog (Florence, 2017), 17$33,22$.

26. Giuseppe Marchini, “Leonardo e le scale,” Antichità Viva 24, nos. 1-3 (1985): 180-85; also see Gabriele Morolli, "Lorenzo, Leonardo e Giuliano, da San Lorenzo al Duomo al Poggio a Caiano," Quasar 3 (1990): 5-14, and "Architetture laurenziane," in Per bellezza, per studio, per piacere: Lorenzo il Magnifico e gli spazi dell'arte, ed. Franco Borsi (Florence, 1991), 195-306, 260. This relationship has been discussed by, among others, Antonio Natali, Leonardo: Il giardino delle delizie (Cinisello Balsamo, 2002), 87-101, and "La predizione di Isaia," 22. 


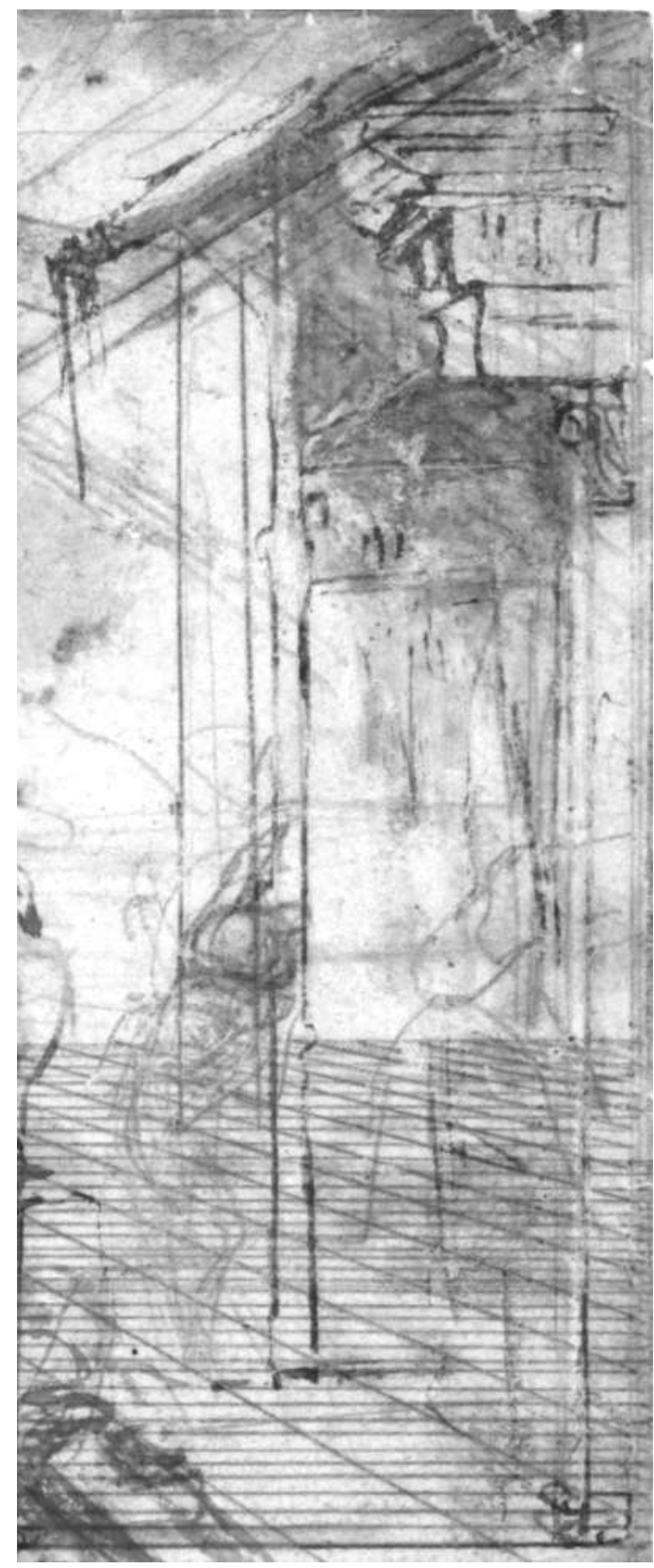

Figure 5. Detail from Leonardo da Vinci, Perspectival Study for the Adoration of the Magi, 1481. Pen and ink, traces of silverpoint and white on paper. (Inv. 436E recto, Gabinetto Disegni e Stampe degli Uffizi, Florence.) Color version available as an online enhancement. 
however, Amedeo Belluzzi has convincingly shifted the beginning of construction of Poggio a Caiano to the years 1489-90-placed by earlier historiography between 1474 (for the first design) and 1485 (the year work began). ${ }^{27}$ Furthermore, Belluzzi established that the villa was only finished at the time of Pope Leo X (1513-21). This major shift in the date of the construction of Poggio a Caiano necessitates a different explanation for their stylistic resemblance and the possibility of the existence of a common source for the Medicean villa and for Leonardo's ruined building. ${ }^{28}$ Howard Burns, in fact, related the architecture of the Adoration and of the basement of the villa of Poggio a Caiano to a drawing of Francesco di Giorgio in the Uffizi (fig. 6). ${ }^{29}$ The folio in question (GDSU inv. 327Ar) shows the representation of the podium of the Temple of Divus Claudius on the Caelian Hill in Rome, as deduced from a note on the page. ${ }^{30}$ Motifs from this monument were borrowed widely throughout the Renaissance, especially the west portico (the side toward the Palatino). ${ }^{31}$ It was mentioned by Francesco di Giorgio in the Codice Salluzziano and by Giuliano da Sangallo in the Codice Barberiniano, among others. ${ }^{32}$ The particular interest among quattrocento architects in this structure could be linked to the use of the area as a quarry for construction materials for important Roman building sites. Thus when describing the work of Giuliano da Maiano at the Palazzo Venezia (in the 1460s-70s), Vasari would refer to the extensive use of plundered travertine (di spoglio) coming from an area near the Coliseum that

27. Amedeo Belluzzi, "La villa di Poggio a Caiano e l'architettura di Giuliano da Sangallo," in Giuliano da Sangallo, ed. Amedeo Belluzzi, Caroline Elam, and Francesco Paolo Fiore (Milan, 2017), 374-86, 374. For an early dating of the building, see Philip E. Foster, “A Study of Lorenzo de' Medici's Villa at Poggio a Caiano” (PhD diss., Yale University, 1974), followed by the subsequent historiography of the villa.

28. Shifting the start of construction of the villa to 1489-90 leads to the possibility of an overlap between the works of Leonardo and Giuliano da Sangallo based on shared drawings or models, as described in Sabine Frommel, "Giuliano da Sangallo and Leonardo da Vinci: Cross-Pollination or Parallels?" in Illuminating Leonardo: A Festschrift for Carlo Pedretti Celebrating His 70 Years of Scholarship, 1944-2014, ed. Constance Moffatt and Sara Taglialagamba (Leiden, 2016), 85-99. Even if this were true, Leonardo's choice remains to be explained by Frommel.

29. Howard Burns, "Scheda XX.17," in Francesco di Giorgio architetto, ed. Francesco Paolo Fiore and Manfredo Tafuri, exhibition catalog (Milan, 1994), 360-62.

30. Burns, "Scheda XX.17"; Adriano Prandi, Il complesso monumentale della basilica celimontana dei SS. Giovanni e Paolo (Rome, 1953).

31. Nerino Ferri, Indice geografico-analitico dei disegni di architettura civile e militare, esistenti nella R. Galleria degli Uffizi in Firenze (Rome, 1885), index; Antonio Maria Colini, Storia e topografia del Celio nell'antichità: Con rilievi, piante e ricostruzioni, Atti della Pontificia Accademia Romana di Archeologi 3, Memorie 7 (Rome, 1944), esp. 138-44.

32. Francesco di Giorgio Martini, Trattati di architettura, ingegneria e arte militare, ed. Corrado Maltese (Milan, 1967), vol. 1, plate 144 (Salluzziano, fol. 78v); Stefano Borsi, Giuliano da Sangallo: I disegni di architettura e dell'antico (Rome, 1985), 48 (Cod. Barb. Lat. 4424, 3v). 


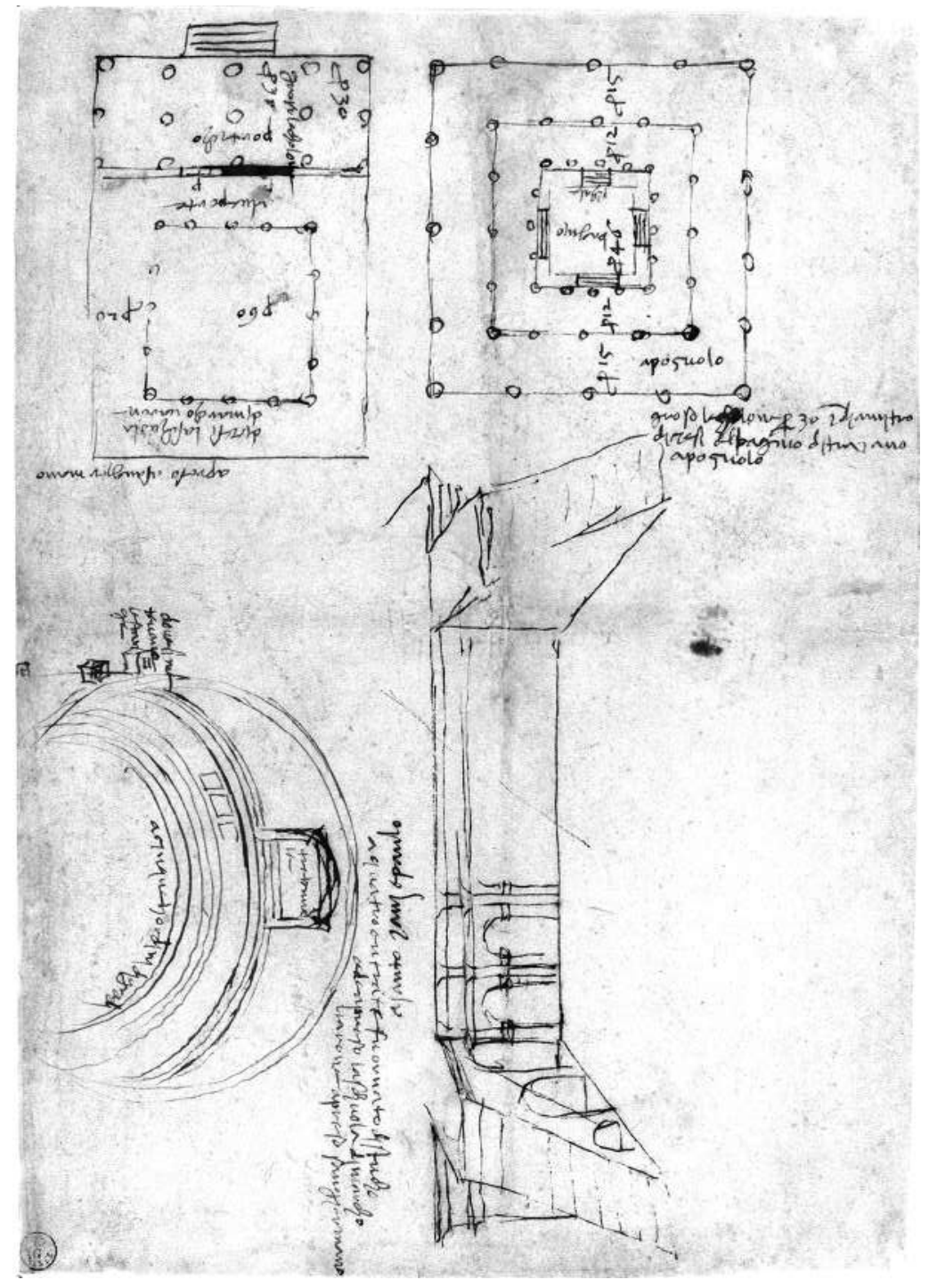

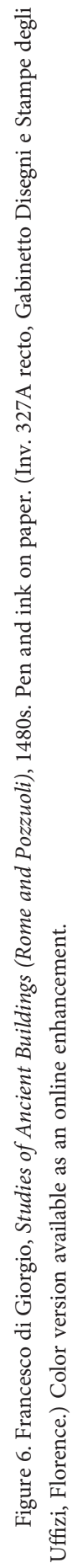


archeologists Rodolfo Lanciani and Antonio Colini have identified as the artificial plateau of the Claudianum. ${ }^{33}$

In GDSU 327Ar, Francesco di Giorgio gives no sign of the presence of bugne (rough stone blocks), but Giovanni Antonio Dosio, in the following century, would delineate a view of the Caelian Hill from the Palatine (fig. 7), showing the same side of the perimeter of the substructure in a similar way. Dosio presents the facade of Claudianum as even more simplified, and he heightens, over all, the theme of the sequential arches on pillars. In contrast, in another very different kind of drawing, Dosio depicts the arches with extreme realism and notes the type of stone and rustic order (fig. 8). It therefore seems to be case that there were two ways of representing the west side of the Claudianum substructure, with and without bugne, as the drawings of Francesco di Giorgio and Dosio demonstrate, but almost always without stairs. ${ }^{34}$ One way shows the monumentality of the sequence of arches on pillars, establishing the compositional or syntactic logic rather than decorative expression. The other, instead, aims to render the sculptural qualities of the rustic order.

The controversial dating of the Taccuino di viaggio of Francesco di Giorgio from which this drawing comes (fig. 6) makes it difficult to establish unambiguously the relationship between Francesco di Giorgio's work and the Adoration of Leonardo, even if it does seem likely that this folio is later than Leonardo's painting. ${ }^{35}$ For the moment, the question of what exactly connects the building in the

33. Giorgio Vasari, Le vite dei più eccellenti pittori, scultori ed architettori, ed. Gaetano Milanesi, 9 vols. (Florence, 1878), 2:472. Rodolfo Lanciani, Storia degli scavi di Roma e notizie intorno alle collezioni romane di antichità, 1: 1000-1530 (Rome, 1902), 71; Colini, Storia e topografia, 140. Also, Giuliano da Sangallo was probably present at Rome in 1467; Eugène Müntz, Les Arts à la Cour des Papes pendant le XVe et le XVIe siècle (Paris, 1879), 16-17; Cornelius von Fabriczy, "Giuliano da Sangallo: Chronologischer Prospekt der Lebensdaten und Werke," Jahrbuch der Königlich Preussichen Kunstsammlungen 23 (1902): 1-42.

34. The double stairs in Francesco di Giorgio's drawing (also in Leonardo's Adoration of the Magi and at Poggio a Caiano) are a plausible and reasonable addition of Renaissance culture: they were required for the considerable jump in elevation between the base of the Caelian and the artificial piazza of the lost temple. See Colini, Storia e topografia, 138.

35. The chronology and the number of trips to Rome made by Francesco di Giorgio is a subject on which scholars do not agree. Some date his presence there to 1460 or 1470 , thus much earlier than his move to Naples (1491-96); Francesco Paolo Fiore, Città e macchine del '400 nei disegni di Francesco di Giorgio Martini (Florence, 1978), 64-65, and "Review of Christopher Ericsson, Roman Architecture Expressed in Sketches by Francesco di Giorgio Martini," Journal of the Society of Architectural Historians 42, no. 2 (1983): 201-2. Fiore, in fact, does not exclude contact with Alfonso Duca di Calabria over a period of time between $1479-80$ and 1491-95, thus anticipating the trip to Rome that often is dated to 1491 , or his better documented stay in Naples. A date in the 1480 s is accepted by Michael Waters, who reconstructs the historiographical debate in "Francesco di Giorgio and the Reconstruction of Antiquity: Epigraphy, Archeology, and Newly Discovered Drawings," Pegasus 16 (2014): 9-102, 26-27. 


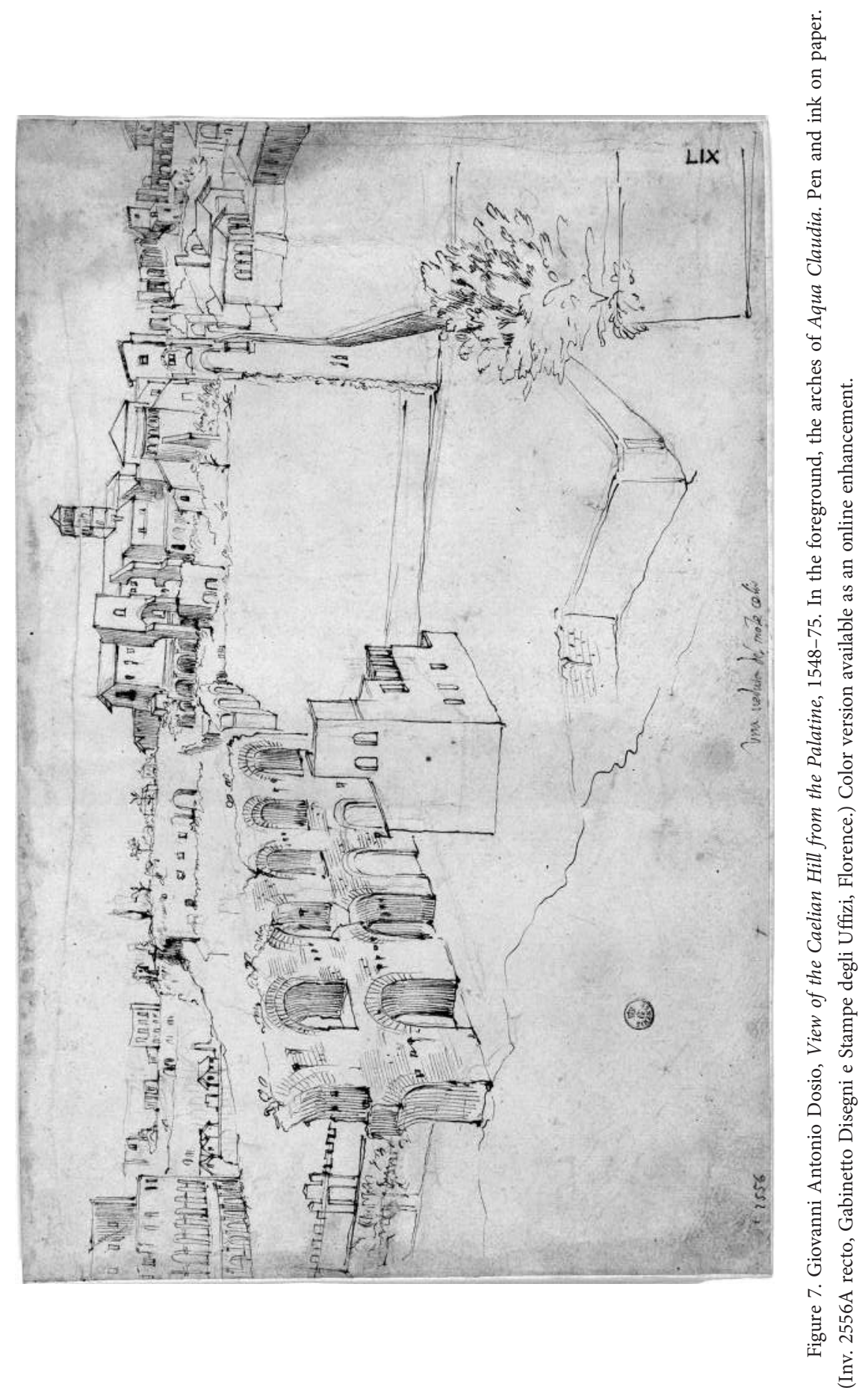




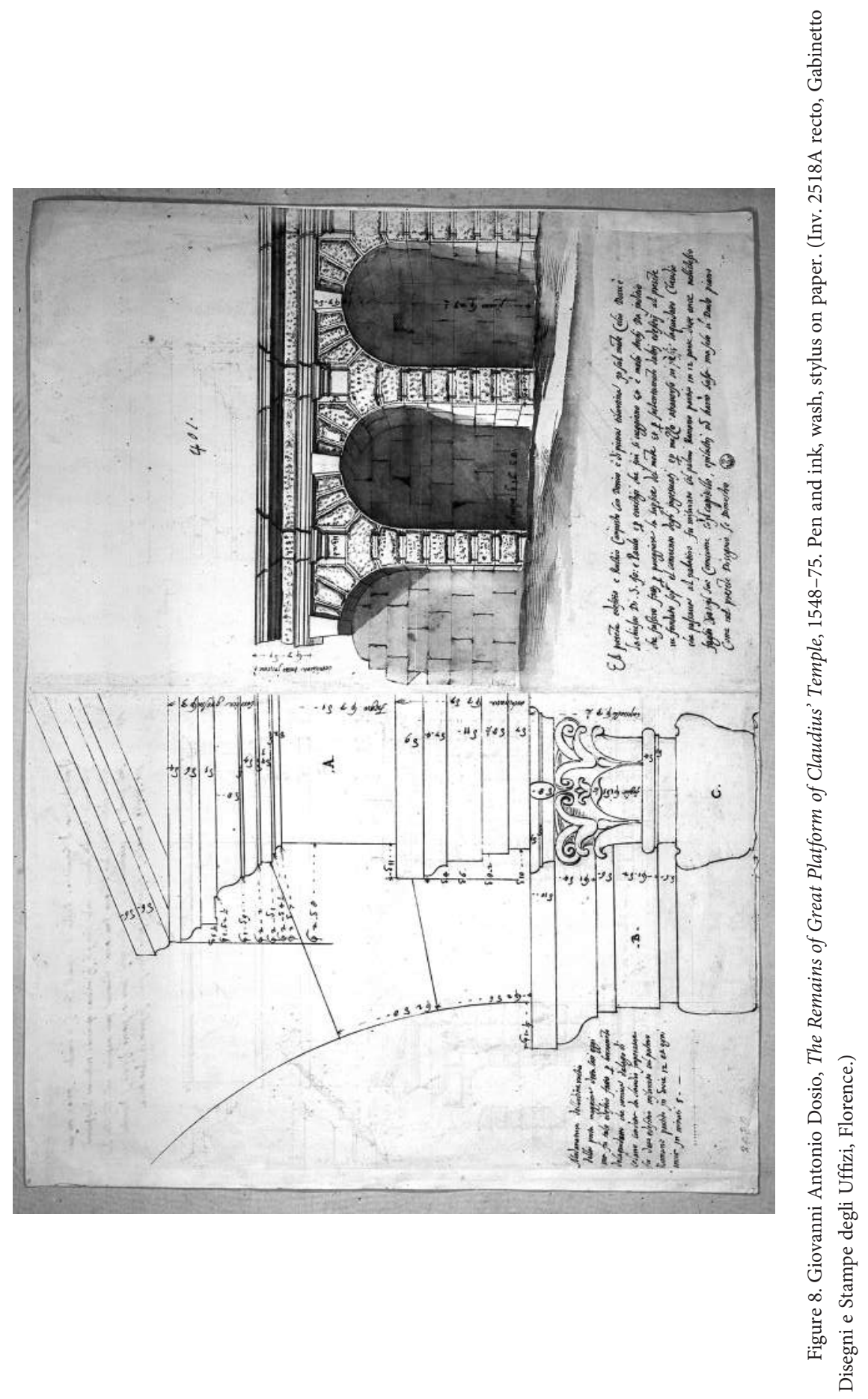


Adoration, the basement of the Medici villa of Poggio a Caiano, and the western side of the substructure of the Claudianum drawn by Francesco di Giorgio remains unanswered. ${ }^{36}$

Yet one needs to investigate the fifteenth-century understanding of these ancient substructures to determine whether a specific reason can be found for Leonardo's choice. Biondo Flavio had (erroneously) traced the imposing structure of the Claudianum to the ancient Curia Hostilia. ${ }^{37}$ Some years later, studies of Rome's topography developed in Pomponio Leto's humanistic circle would identify it as the remains of the palace of Tullus Hostilius. ${ }^{38}$ A final reference to the massive substructure of the Claudianum is found in an epigram of the Spectacula of Martial. ${ }^{39}$ In his commentary on Martial from 1480, Domizio Calderini would compare the monument to a kind of porticus or arcade surrounding an open space. The "porticus of Claudius" is presented as an architectural form strictly tied to the Flavian amphitheater that comes to be illustrated as a structure that was destroyed and then rebuilt. ${ }^{40}$ Leonardo therefore may have chosen to portray the Curia Hostilia

36. Burns, "Scheda XX.17."

37. Biondo Flavio, Roma instaurata (Rome, 1446-48), Libro II, LXIII (1st printed ed. 1471; I consulted Roma instaurata in the 1481 ed.). The location of the Curia Hostilia has now been identified as the area of the Chiesa dei Santi Luca e Martina, according to locations given in antique sources; see Francesco Coarelli, "Curia Hostilia," in Lexicon Topographicum Urbis Romae, ed. Eva Margareta Steinby (Rome, 1993), 1:331-32. The collection of sources on the Curia Hostilia in the volume of Paolo Carafa, Il comizio di Roma dalle origini all'età di Augusto (Rome, 1998), refers to a structure on the edge of the Forum and thus is not useful for our discussion in that it does not take into consideration the antique or Renaissance sources that record the early, different hypotheses for the location of the original structure.

38. Titus Livius, Decades, bk. 1:31, 1-2, and Pliny, Naturalis Historia, II, 53. In Pomponio Leto's Regionario in the Biblioteca Marciana edition, with additions attributed to an anonymous student of his "school," we read: "Regia Tulli Hostilii et templum quod in curiam redegit Tullus ordini a se aucto, idest patribus minorum gentium"; see Roberto Valentini and Giuseppe Zucchetti, Codice topografico della città di Roma (Rome, 1953), 1:193-258, 209. The catalog of the fourteen regions edited by Leto has no date but was written between 1469-70 and 1488; see Maria Accame Lanzillotta, "Per la storia della topografia: Pomponio Leto e la topografia di Roma," Rivista di Topografia Antica 7 (1999): 187-99, 187 n. 1. The archaic complex was destroyed by lightning, according to Livy and Pliny, supposedly because of a mistaken attempt of the third king of Rome to invoke a lightning bolt and commit a clear act of impiety. Tullus Hostilius was a Sabine king, but it was thought that he, along with Numas Pompilius and Ancus Marcius, introduced Etruscan customs to Rome; Gabriele Morolli, "Vetus Etruria": Il mito degli Etruschi nella letteratura architettonica nell'arte e nella cultura da Vitruvio a Winkelmann (Florence, 1985), 27. Pliny also notes that the power of governing lightning was the prerogative of the Etruscans.

39. Colini, Storia e topografia, 138.

40. Consulted edition: Domitii Calderini Veronensis Commentarii in M. Valerium Martialem ad clarissimum virum Laurentium Medicem Florentissimum Petri Medici (Venice, 1480), [c.5]. The editio princeps was printed in Rome in 1474; see Anastasia Viti, "Per la storia del testo di Marziale nel secolo XV: I 'Commentarii in M. Valerium Martiale’ di Domizio Calderini,” Eikasmos 15 (2004): 401-34. Calderini, in 1473, presented Lorenzo il Magnifico with the manuscript version of the work. The illuminated text is in the Biblioteca Medicea Laurenziana, Florence, MS Plut. 53.33. Poliziano, furthermore, 
in the Adoration, but in the absence of a linear and direct link between the nature of the antique building and the subject portrayed in the painting (and given the lack of research on the role of the Augustinian fathers of San Donato a Scopeto in defining the iconography of the painting), it is only possible to propose a few hypotheses.

Leonardo's invocation of the Curia Hostilia might bring to mind, by synecdoche, ancient Rome. ${ }^{41}$ Or it could be connected to the desire to represent a famous and grandiose building in ruins and thus serve the particular taste that marks the artistic culture of the Laurentian age. The majesty that characterizes its appearance can be said to epitomize classicism and those values that the birth of Christ would shatter. The presence of collapsed or ruined structures often characterizes the backgrounds of Adorations painted over the course of the Renaissance, alluding to themes specified in the influential Golden Legend of Jacobus de Voragine (126098), so reinforcing the leitmotif of the Christian era that rises over the ruins of pagan civilization. ${ }^{42}$ Similar observations can be made by accepting the interpretation of the ruins of the Claudianum as a porticus according to Calderini, that is, an ancient building destroyed with the birth of Jesus. In addition, during the 1470s or 1480s, humanist Alessandro D’Alessandro would note a connection between the Curia Hostilia and the Templum Pacis. D'Alessandro describes how while exploring the ruins of the Templum Pacis (identified as the Basilica of Maxentius in the Renaissance), Pomponio Leto discovered an inscription, writing: "grandioribus literis extantibus, effractum ibi marmor legimus hac inscriptione: IN CURIA HOSTILIA." 43 The

describes how Calderini had collated a codex of Martial for the public library of the Medici: Alessandro Perosa, “Calderini Domizio,” Dizionario Biografico degli italiani 16 (1973): 597-604, 600.

41. The very ancient Curia as a symbol of Rome, ancient and modern, was used in the work of Francesco Sperulo dedicated to the Villa Medici at Ponte Milvio (ca. 1519), to evoke the place where Giovanni di Bicci had lived as papal banker; Elet, Architectural Invention, 206 n. 47 (the note on this specific passage of Sperulo's text is by Nicoletta Marcelli).

42. Antonio Pinelli, "Feste e trionfi: Continuità e metamorfosi di un tema," in Memoria dell'Antico nell'arte italiana, vol. 2, I Generi e i temi ritrovati, ed. Salvatore Settis (Turin, 1985), 281-352, 290-91; Hui, "Birth of Ruins." The relevant passage is Iacopo da Varazze, Legenda aurea, critical ed., ed. Giovanni Paolo Maggioni, 2 vols. (Florence, 1998), 1:66, bk. 6, “'De nativitate domini’: Quinto per miraculi evidentiam. Rome enim, ut testatur Innocentius papa tertius, duodecim annis pax fuit; igitur Romani templum pacis pulcherrimum construxerunt et ibi statuam Romuli posuerunt. Consulentes Apollinem quantum duraret, acceperunt responsum quosque virgo pareret. Hoc audentes dixerunt: 'Ergo in eternum durabit.' Impossibile enim credebant quod unquam pareret virgo. Unde in foribus templi titulum hunc scripserunt. 'Templum pacis eternum.' Sed in ipsa nocte qua virgo peperit, templum funditus corruit et ibi est modo ecclesia Sante Marie Nove."

43. Patricia Osmond, “Alessandro D’Alessandro," Repertorium Pomponianum (http://www .repertoriumpomponianum.it/pomponiani/d_alessandro_alessandro.htm). D’Alessandro was in Rome from 1473 until 1485 and then spent time between Rome and Naples, the city in which he resided until 1493; Mauro De Nichilo, “D’Alessandro, Alessandro," Dizionario Biografico degli Italiani 21 (1985): 729-31. 
Templum Pacis plays an important role in the Golden Legend. In the paragraph dedicated to Christ's birth, the Templum Pacis is said to have partially collapsed at the moment of the Virgin's parturition: "The fifth proof is a miraculous event. As Pope Innocent III testifies, during the twelve years when Rome enjoyed peace, the Romans built a Temple of Peace and placed a statue of Romulus in it. Apollo was asked how long the temple would stand, and the answer was that it would be until a virgin bore a child. Hearing this, the people said that the temple was eternal, for they thought it impossible that such a thing could happen; and an inscription, TEMPLUM PACIS AETERNUM, was carved over the doors. But on the very night when Mary bore Christ, the temple crumbled to the ground, and on its site the church of Santa Maria Nuova stands today." 44

Finally, one can add to this broad range of plausible references to Roman monuments for the building portrayed by Leonardo, with its combination of arcades on pillars with flights of stairs, the so-called Palazzo di Mecenate also in Rome. ${ }^{45}$ Palatium Neronis is another plausible model for the villa of Lorenzo il Magnifico at Poggio a Caiano (fig. 9). ${ }^{46}$

Yet if some elements seem to define an iconographic thread that originates with antiquity and thus echoes a possible reference in the Golden Legend, other specific components of the architecture point to a different reading: the dominant structure in the painting may evoke not a building in Rome but the Temple of Jerusalem. ${ }^{47}$ Biblical texts (as well as other ancient sources) helped to establish a specific

44. Jacobus de Voragine, The Golden Legend: Readings on the Saints, trans. William Granger Ryan (Princeton, NJ, 1993), 1:38-39. Giovanni Rucellai, in the memoirs of his trip to Rome in 1450, records having visited the Templum Pacis: Giovanni di Pagolo Rucellai, Zibaldone, ed. Gabriella Battista (Florence, 2013), 126: "Templum pacis che si dice un tempio di Idoli et che i Romani dicevano ch'egli aveva a durare insino che una vergine partorisse et che apunto cascò et rovinò la notte che naque Nostro Singore Giesù Cristo et ancora v'è in piè una colonna di marmo achalanata che gira braccia XII la groseza" [The Templum Pacis is a temple of idols that the Romans said would last until a virgin gave birth. In fact it fell and was ruined the night that Our Lord Jesus Christ was born and there is yet standing a fluted marble column that is twelve braccia around]. Furthermore, in the memorable decorations for the Feast of San Giovanni in 1454, among the sets created for the occasion, according to a contemporary account, was an edifice representing "Templum pacis, with the building of the Nativity"; Rab Hatfield, “The Compagnia de' Magi," Journal of the Warburg and Courtauld Institutes 33 (1970): 10761,114 n. 40.

45. Hubertus Günther, "Dal palazzo di Mecenate a Palazzo Farnese: La concezione rinascimentale del palazzo," in Aspetti dell'abitare in Italia tra XV e XVI secolo, ed. A. Scotti Tosini (Milan, 2001), 221; Cammy Brothers, "Reconstruction as Design: Giuliano da Sangallo and the 'palazo di mecenate' on the Quirinal Hill," Annali di Architettura 14 (2002): 55-72; Hubertus Günther, "Fantasie scritte e disegnate a confronto: La rappresentazione di edifici antichi nei disegni della collezione Santarelli," in Grafie di immagini tra Quattrocento e Cinquecento, ed. Marzia Faietti and Gerhard Wolf (Venice, 2008), 12134, 130.

46. Brothers, "Reconstruction as Design," 68.

47. Ferretti, "Un arcipelago di simboli," 156-57. 


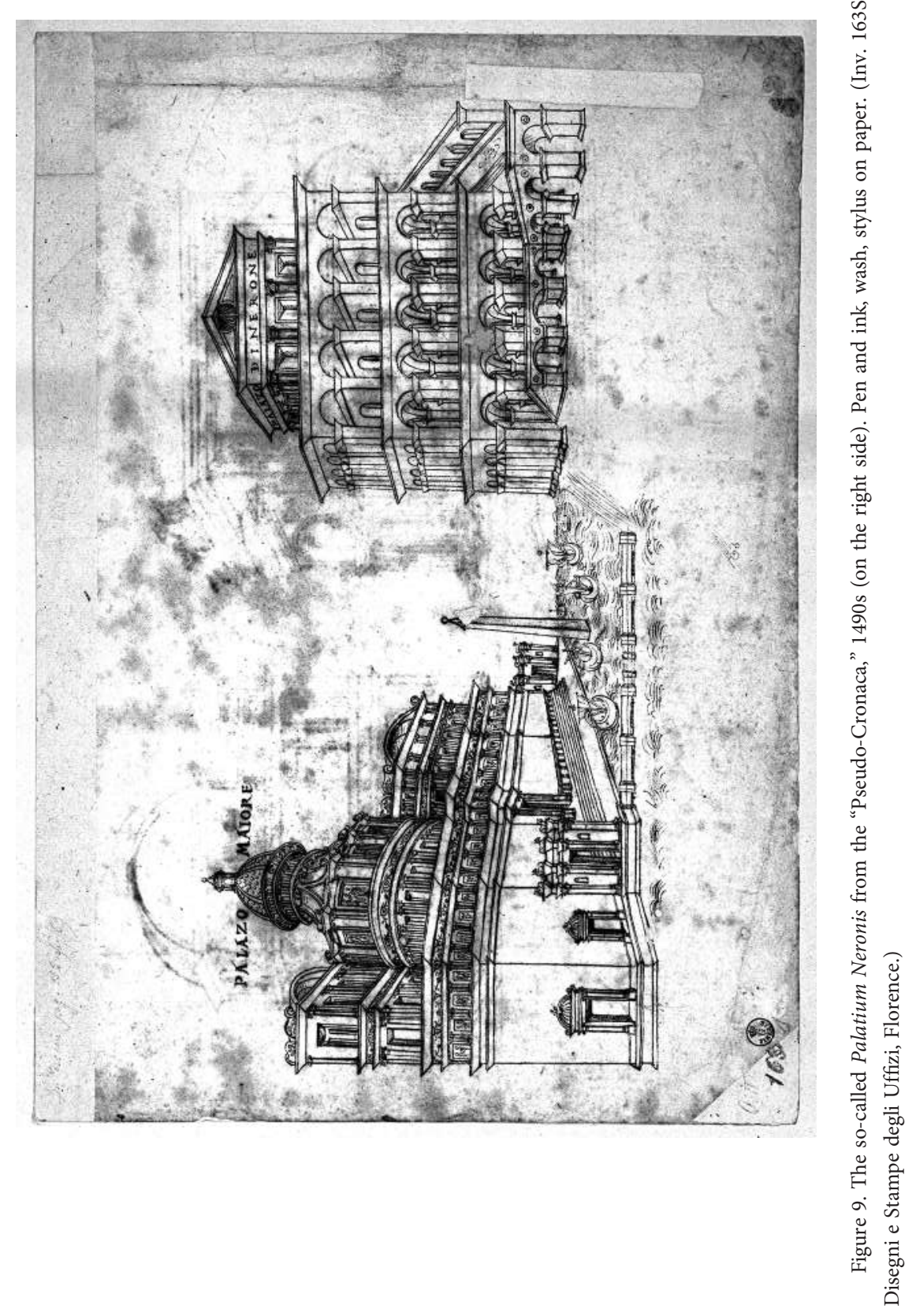


image of Solomon's temple in Jerusalem, as the iconography of the city (fig. 10) came to be consolidated during the Middle Ages. ${ }^{48}$ Central to this image is an elevated level with a temple in the middle, accessed by perpendicular staircases. These elements, furthermore, characterize the image of the temple from the midfourteenth century on, becoming a widespread presence in the portrayal of its structure in scenes of the Presentation of the Virgin at the Temple. ${ }^{49}$ The accounts of pilgrims had already reinforced the transmission of an image of the vast temple area with some peculiarities that become actual characteristics of the monumental holy area for the three great monotheistic religions. The visual sources that popularized possible schematic solutions for the reconstruction of the (second) temple of Jerusalem destroyed in $\mathrm{AD} 70$ by Titus can be integrated, as is known, with descriptions of pilgrims and travelers. For example, Alessandro Rinuccini, Dominican friar of the Florentine Convent of San Marco, writes in his memoirs, "still visible, before the entrance of the temple [of Solomon], are the stairs with fifteen steps, which, according to what is said, the glorious Mother Virgin miraculously climbed on her own without any help as a young child at the tender age of three and no

48. For the biblical passages, see below. Among the ancient sources, Flavius Josephus offers one of the most detailed descriptions of the temple of Jerusalem. He describes the temple in two different works: in the Antiquities of the Jews (VIII, II, 10), and in the Jewish Wars (V, 1-5), where the battle that occurs outside of the temple takes place. The printed editions of the latter text (after the first of 1480) were widespread, especially the vernacular edition published in Florence in 1493. One Florentine bookseller in 1495, according to the inventory of books found in his shop at the moment of his death, had thirty copies of Flavius Josephus in the vernacular. See Christian Bec, Cultura e società a Firenze nell'età della Rinascenza (Rome, 1981), 186. The works of Flavius Josephus are among Alberti's sources. The exemplary role of the temple of Jerusalem in terms of monumentality and magnificence is recalled more than once in the De re aedificatoria: Leon Battista Alberti, L'architettura, ed. Giovanni Orlandi and Paolo Portoghesi, 2 vols. (Milan, 1966), bk. 2, chap. 3 (1:108); bk. 6, chap. 11 (2:510); bk. 6, chap. 12 (2:512); bk. 7, chap. 2 (2:614), where a fire is described at the "sacred portici of Jerusalem" is of particular significance for this discussion. For what was known about the destroyed temple in earlier centuries, see Carol Herselle Krinsky, "Representations of the Temple of Jerusalem before 1500," Journal of the Warburg and Courtauld Institutes 33 (1970): 1-19. On the iconography of Jerusalem during the Middle Ages and beyond, see Alessandro Rovetta, "L'immagine di Gerusalemme negli itinerari di pellegrini e crociati e nelle riproduzioni topografiche tra XII e XIV secolo," in Il cammino di Gerusalemme: Atti del convegno, Bari-Brindisi-Trani, 18-22 maggio 1999, ed. Maria Stella Calò Marianai (Bari, 2002), 607-18; Elizabeth Ross, Picturing Experience in the Early Printed Book: Breydenbach's Peregrination from Venice to Jerusalem (Philadelphia, 2014), 37-38, 168-70; Frederike Timm, Der Palästina-Pilgerbericht des Bernhard von Breidenbach und die Holzschnitte Erhard Reuwichs: Die "Der Peregrinatio in terram sanctam" (1486) als Propagandainstrument im Mantel der gelehrten Pilgerschrift (Stuttgart, 2006); Danila Jacazzi, "Haec est via ad Terram Sanctam: Rotte, città e architetture dei viaggiatori nel Mediterraneo," in Spazi e culture del Mediterraneo, ed. Massimo Giovannini, Marinella Arena, and Paola Raffa (Naples, 2015), 1055-65.

49. Ferretti, "L'architettura nell'Adorazione dei Magi," 112; Philine Helas, "Sui gradini del tempio: Il tempio e la scala nell'architectura picta tra il XIV e il XVI secolo," in Frommel and Wolf, Architectura picta nell'arte italiana, 43-67, 48-50. 
more." 50 The number of steps mentioned in the passage of Rinuccini corresponds to that transmitted by the apocryphal tradition of the episode of the Presentation of the Virgin at the Temple, acknowledged by Taddeo Gaddi in the Baroncelli Chapel in Santa Croce in Florence and repeated by Leonardo in the Adoration. ${ }^{51}$

Biblical passages on Solomon's Temple relevant for Leonardo's painting include the Vision of Ezekiel, which mentions two monumental columns set at the sides of the door of the temple. ${ }^{52}$ The recent restoration of Leonardo's Adoration has made two columns visible. These rise behind the flight of stairs, and some meaningful details have been revealed. On one of these, in fact, we can see the details of the capital: apart from the abacus with concave sides, typical of the Corinthian order, there is a ring of palmettes, calligraphically delineated, decorating the kalathos (fig. 11). The presence of this kind of ornament, together with the imposing shaft, would suggest, once again, a relationship with the Jerusalem complex. In Laurentian Florence, a type of Corinthian capital is used that has a palmette under the abacus (held by two large S-shaped volutes). This is a decorative motif that has been interpreted as a kind of Christianization of the pagan orders of antiquity, defining a real "Solomonic order." ${ }^{53}$ Furthermore, the Book of Ezra describes the reconstruction of the temple after the Babylonian exile, with specific references to the building site, including the presence of workers and the arrival of religious leaders to supervise the work. ${ }^{54}$ A drawing by Jan Van der Straet (1589) portraying this episode contains some of the elements also present in Leonardo's Adoration: a

50. "Vedesi anchora, dinanzi allo entrare del tempio [di Salomone], la schala de' gradi XV, la quale, secondo che ssi dice, salie per sé stessa, sana altro adiutorio, miracolosamente la gloriosa madre Vergine Maria, sendo fanciullina picchola, consistuta nella etate tenera di anni iii e non più": Alessandro di Filippo Rinuccini, Sanctissimo peregrinaggio del Sancto Sepolcro 1474, ed. Andrea Calamai (Ospedaletto, 1993), 163.

51. For pilgrims' travel descriptions, see Franco Cardini, In Terrasanta: Pellegrini italiani tra Medioevo e prima età moderna (Bologna, 2002); Antonio Lanza and Marcellina Troncarelli, eds., Pellegrini scrittori: Viaggiatori toscani del Trecento in Terrasanta (Florence, 1990). For the steps of the temple: Helas, "Sui gradini del tempio," 49. These different sources furnish a series of denotative elements for the Jerusalem complex, including the meaningful presence of uneven levels, the contrast between the internal richness and the austere simplicity of the outside, and the characterization of piers or columns present in various levels of the building with palmette capitals; see Ferretti, "Un arcipelago di simboli," 156-57.

52. Ezek. chap. 40, 49: "The length of the porch was twenty cubits, and the breadth eleven cubits; and it was by steps that it was ascended; and there were pillars by the posts, one on this side, and another on that side."

53. This is illustrated, with iconographic sources, in Ferretti, "Un arcipelago di simboli," 156-57. For "Solomonic order," see Gabriele Morolli, "L"elocutio' dei capitelli," in L'architettura di Lorenzo il Magnifico, ed. Gabriele Morolli, Cristina Acidini Luchinat, and Luigi Marchetti, exhibition catalog (Milan, 1992), 272-77, 277. Leonardo's capital differs from these examples in that the Corinthian reference remains only for the shape of the abacus.

54. Ezra, chap. 3, 6-7. 


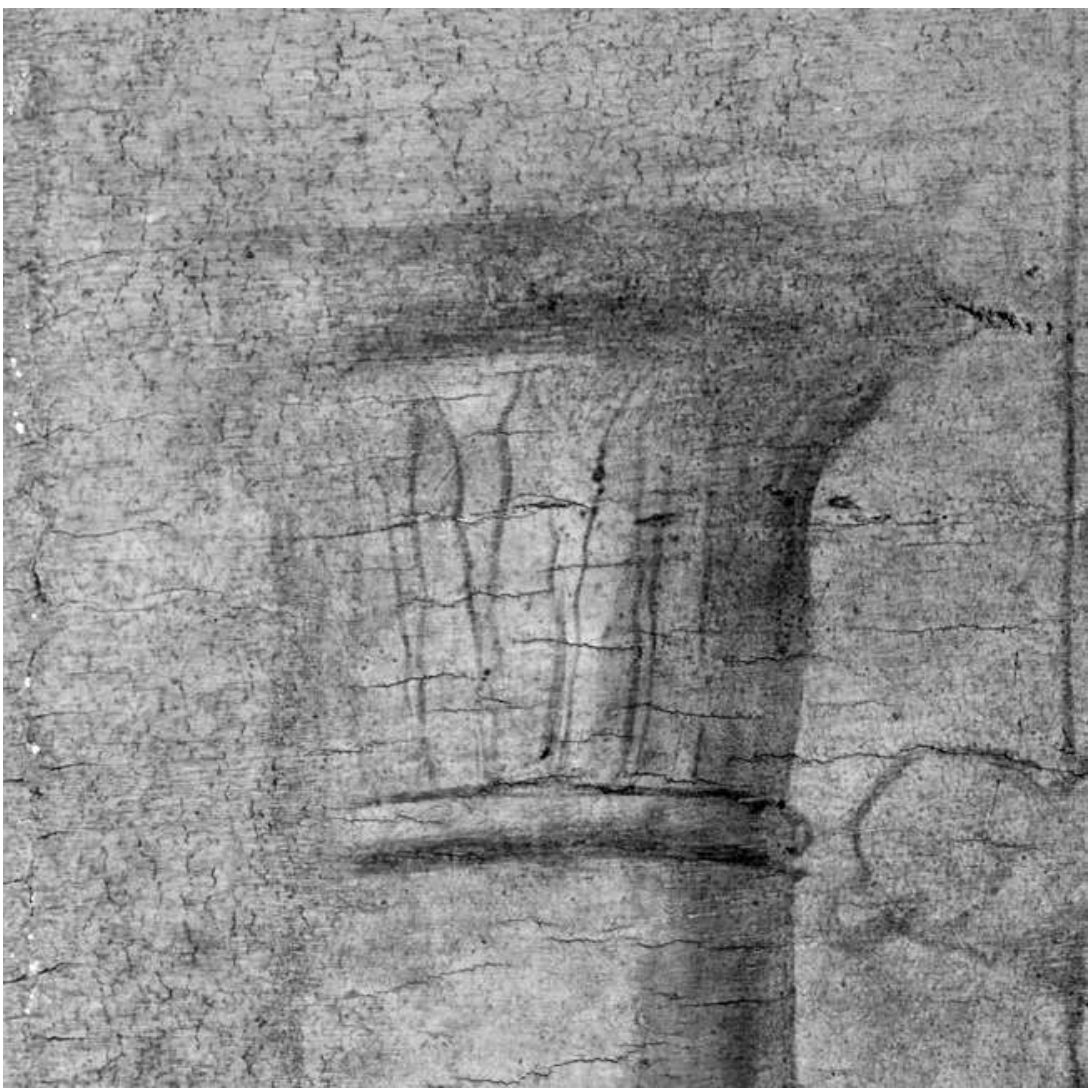

Figure 11. Detail with the column from Leonardo da Vinci, Adoration of the Magi, 1481. Oil on wood. (Galleria degli Uffizi, Florence.) Color version available as an online enhancement.

massive lower level for the temple; perpendicular stairs; and, most importantly, the scene of construction underway (fig. 12). ${ }^{55}$

What function would the ruined Temple of Solomon have served in the background of the Adoration? Numerous passages of the Old and New Testaments mention the destruction of the Temple of Jerusalem in relation to Christ as the Messiah. The reference to Jerusalem and its temple in ruins in the context of the representation of the Adoration can be related to the prophecy of the destruction of the monument of the Jews, cited in a discourse of Jesus that is found, with some variations, in all three synoptic gospels. In the Gospel of Luke, for example, we read: "And shall lay thee even with the ground, and thy children within thee; and they

55. Marjolein Leesberg, catalog entry 113, in Stradanus, 1523-1605: Court Artist of the Medici, ed. Alessandra Baroni and Manfred Sellink, exhibition catalog (Turnhout, 2012), 309, 310-13. 


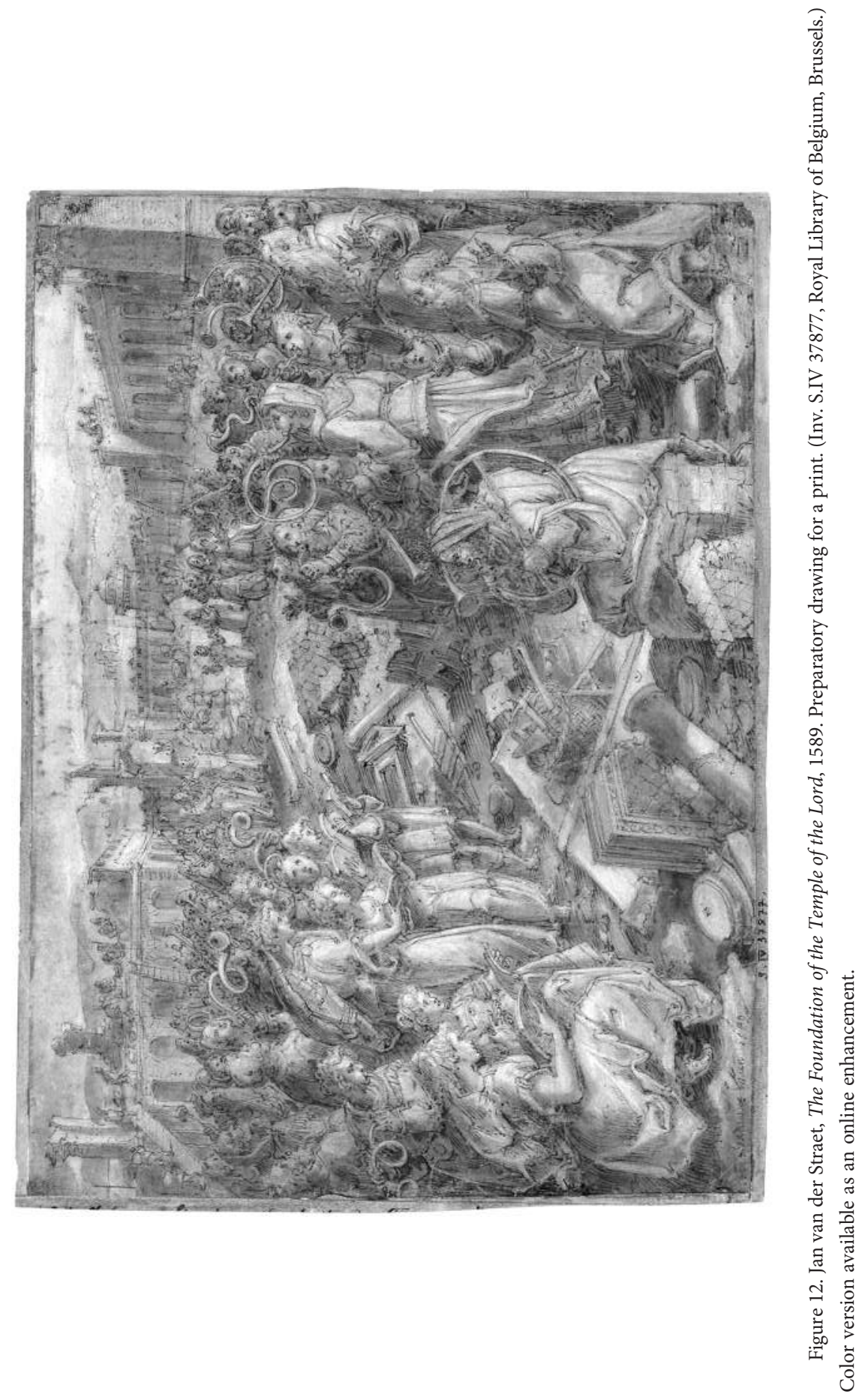


shall not leave in thee one stone upon another; because you did not recognize the time of God's coming to you." 56 The temple's destruction is also foretold in passages from Ezekiel to Daniel and from Isaiah to Zacharias. In the Apocalypse of John we learn that, in the "new Jerusalem," the temple of Solomon no longer exists: "and I saw no temple therein: for the Lord God Almighty and the Lamb are the temple of it." 57

The idea that the coming of Christ made way for the new foundation of the temple as a metaphor for the Christian Church superseding Judaism especially resonates in the pages of Della religione christiana of Marsilio Ficino. ${ }^{58}$ The twentyseventh chapter is dedicated to the testimony of the prophets of Christ, where Ficino gathers the words of the prophets who foretold the coming of Christ and annotates a number of passages that refer to the binomial temple of JerusalemJesus. ${ }^{59}$ The establishment of the Platonic Academy under Ficino and with the Medici's patronage (at first Cosimo the Elder and then Lorenzo) has been carefully studied. ${ }^{60}$ Humanists and artists assiduously frequented the academy, located in the Villa Medici at Careggi. Leonardo was no stranger to this academy, and he was acquainted with numerous personalities who were part of it. ${ }^{61}$

If an evocation of the Temple of Solomon could be recognized in the building of the Adoration, then Leonardo's painting would add a considerable piece to the picture that describes the bond built by Florence toward the end of the Middle Ages (along with other Italian cities) with the celestial and earthly Jerusalem. ${ }^{62}$

56. Luke 19:44, King James Bible.

57. Rev. 21:22, King James Bible.

58. Composed between 1474 and 1475, with the Italian version appearing in 1475, one year earlier than the publication in Latin; see Cesare Vasoli, "Il De christiana religione di Marsilio Ficino," Bruniana and Campanelliana 13, no. 2 (2007): 403-28.

59. Consulted edition: Marsilio Ficino, Della religione christiana (Florence, 1568), 124. See the appendix for additional citations: app. sec. 1, the temple of Jerusalem is referenced in the parts dedicated to Haggai; sec. 2, the portico, the dominant element of the architecture portrayed by Leonardo, as a metaphor of the holy site, is expressly recorded in the commentary of Ficino on a passage of Deuteronomy; secs. 3 and 4, the importance that Leonardo gives to the element of stone is reflected, furthermore, in two passages of the work by Ficino, dedicated respectively to commentary on David and Zacharias.

60. Some important sources include Arthur Field, The Origins of the Platonic Academy of Florence (Princeton, NJ, 1988); James Hankins, Plato in the Italian Renaissance (Leiden, 1991); Michael J. B. Allen and Valery Rees, eds., Marsilio Ficino: His Theology, His Philosophy, His Legacy (Leiden, 2002).

61. Carlo Pedretti, Studi vinciani: Documenti, analisi e inediti leonardeschi (Geneva, 1957), 17; Cesare Vasoli, La lalde del sole di L. da Vinci: XII Lettura Vinciana (Florence, 1973). For Leonardo's knowledge of Ficino's works, evidenced by findings in the artist's manuscripts (mediated, e.g., by Landino), see Augusto Marinoni, "Leonardo: 'Libro di mia vocaboli,"” in Studi in onore di Alberto Chiari (Brescia, 1973), 2:756-66; Fulvia Spesso, Leonardo ermetico (Rome, 1996).

62. Alessandro Rovetta, "La Gerusalemme Celeste e la città ideale nell'età dell'Umanesimo," in $L a$ città ideale nella tradizione classica e biblico-cristiana: Atti del convegno, Torino, 2-5 maggio 1985, ed. 
At the same time, meaningful traces of the process of achieving a balance between paganism and Christianity and the search for continuity (if not actual syncretism) between the two cultures were convincingly being brought forward in the Laurentian environment, precisely in those years when Leonardo was at work on Adoration. ${ }^{63}$ The Sassetti Chapel in Santa Trinita, together with the altarpiece of the Adoration of the Shepherds (1485), are prime figurative examples of this process of delineating the connections between classical culture, the Christian message, and the visual arts by depicting classic elements, outlined with protoarchaeological precision. ${ }^{64}$ In particular, the painted architecture of Domenico Ghirlandaio contributes to establishing harmony between religious values and the nascent antiquarian culture. In Ghirlandaio's Adoration of the Shepherds, there are two magniloquent Corinthian pillars supporting a fragment of all'antica entablature. The Holy Family's shelter has only a rudimentary wooden roof, but it is held up by a structure that is recognizably ancient. The contrasting nature of these elements reinforces the significance of antiquity in the scene, portraying continuity between the pagan and the Christian worlds. Equally important is the presence of a sarcophagus behind the Christ Child, on which is carved a prophecy of the augur Fulvio, who was killed during the occupation of Jerusalem by Pompey, and taken from a text by the humanist Bartolomeo della Fonte. ${ }^{65}$ The triumphal arch, on the left, also contributes to the syncretism between the pagan and the Christian world that pervades Ghirlandaio's painting.

Renato Uguglione (Turin, 1987), 269-87. This connection would be reinforced over the course of the quattrocento, culminating in the era of Savonarola: see Lorenza Tromboni, "La restaurazione di Firenze e il mito di Gerusalemme nella predicazione di Girolamo Savonarola: Le prediche sopra 'Aggeo' e il 'Compendio di rivelazioni' (1494-1495)," 133-53; Lorenzo Amato, "Firenze come nuova Gerusalemme," 194-218, both in Come a Gerusalemme: Evocazioni, riproduzioni, imitazioni dei luoghi santi tra Medioevo ed età moderna, ed. Anna Benvenuti and Pierantonio Piatti (Florence, 2013). It seems opportune to cite Rab Hatfield's comment regarding an undated installation for the Feast of the Magi between 1466 and 1469 organized by the Confraternity of the Magi (an expression of Medicean power): "the whole of Florence was the 'image' of Jerusalem." See Hatfield, "Compagnia de' Magi," 115.

63. Francesco Bausi, Umanesimo a Firenze nell'età di Lorenzo e Poliziano: Jacopo Bracciolini, Bartolomeo Fonzio e Francesco da Castiglione (Rome, 2011), 266-70.

64. Aby Moritz Warburg, La rinascita del paganesimo antico (Florence, 1966), 113-46; Eve Borsook and Johannes Offerhaus, "Storia e leggende nella Cappella Sassetti in Santa Trinita," in Scritti di storia dell'arte in onore di Ugo Procacci, ed. Maria Grazia Ciardi Dupré Dal Poggetto and Paolo Dal Poggetto (Milan, 1977), 1:289-310.

65. "Ense cadens. Solymo. Pompei Fulvi[us] Augur Numen. Ait. Quae me conteg[it] Urna Dabit" [Falling on the sword in Jerusalem, Fulvius, augur of Pompey, said the tomb that contains me will yield a god]. See for this topic Francesco Bausi, "La lirica latina di Bartolomeo Della Fonte," Interpres 10 (1990): 87-88. See also Christopher D. Johnson, Publication of Memory, Metaphor, and Aby Warburg's Atlas of Images (New York, 2012), 53. 
These connections, in a nutshell, can be seen in Leonardo's Adoration as well, which fits fully into the Laurentian cultural milieu. Leonardo's painting, furthermore, should be considered a critical turning point for the role of architecture as an evocative element with specific meaning and symbolism in reinventing the iconography of the Adoration of the Magi in a classical key that occurs beginning in the 1480s. In linking Christian religiosity and the "dream of the Antique," painted architecture not only serves to give a perspectival structure to space and demonstrate its fluency with classical language, but it contributes decisively to emphasizing the message through images that painters and patrons entrust to paintings.

\section{APPENDIX}

1. Marsilio Ficino, Della religione christiana (Florence, 1568), 124

"El mare: questo fu quando Christo comando al mare et a' venti, quando soggiugne che la Casa ultima, cioè il secondo tempio, harà maggior gloria che 'l primo, intende perché vedrà il Messia, da poi che in tutte l'altre parti fu più vile et miserabile. Queste cose convengono solo a Gesù Nazareno.... Non aspettino i Giudei edificare per il nuovo Messia più tempio in Gerusalemme, perché Aggeo, qual secondo tempio chiamò l'ultimo in superlativo grado, come se dicessimo ultimissimo. Et che il tempio non si doveva mai rifare lo testimonia Ammiano Marcellino storico gentile, dicendo che volendo Iuliano, la memoria del suo imperio con grandi opere amplificare, fece pensiero di rifare con magnifica spesa il famoso tempio di Gerusalemme: il quale dopo molte et acerbissime guerre, per ossidione da Vespasiano et Tito in fine con difficultà fu destrutto: et allora il detto imperadore commise detta opera a Alipio d'Antiochia, et quando il detto Alipio con grande instantia attendeva al detto edifitio coll'aiuto del rettore della provincia, molte fiamme uscirono su de' fondamenti in modo spaventevole, facendosi fare luogo et consumando spesso di quelli che ivi lavoravano, che non è dubbio come pel detto incendio si ritrahessi da questo edifitio."

[The sea: this was when Christ commanded the sea and the winds, when he added that the Last House, that is, the second temple, would have more glory than the first, because it will see the Messiah, and from then on would in all its other parts be most lowly and miserable. Such things befit only Jesus the Nazarene. . . . Don't wait for the Jews to build another temple for the new Messiah in Jerusalem, because [according to] Haggaeus, that second temple he called the last in absolute degree, as we say, the very last. And that the temple must not ever be redone, testifies Ammianus Marcellinus, Gentile historian, saying that Julian had wanted to 
amplify the memory of his empire with great works, and had the plan to rebuild with magnificent expense the famous temple of Jerusalem: which after many and bitter wars, in the siege of Vespasian and Titus at last, with difficulty, was destroyed: and then he said the emperor commissioned the said work to Alipius of Antioch. And while said Alipius was working with great urgency on said structure with the help of the governor of the province, many flames emerged from its foundations in a terrifying way, opening up space and killing many of those working there, so that there was no doubt that they abandoned the building because of said fire.]

2. Marsilio Ficino, Della religione christiana (Florence, 1568), 177

"Onde Rabi Moise d'Egitto nel Deuteronomio dice, che nelle lettere sacre in molti modi si nomina quel bene, che è spiriturale, et divino, et che si chiama hora Monte di Dio, hora il santo, suo luogo, o vero luogo di santuario, via santa, portico del Signore, tempio del Signore, casa del Signore, et porta del Signore. Questo parla il predetto Moisè. Ancora Rabi Salomone et Rabi Abba stimono l'edificatione del tempio descritta da Ezechiel appartenersi a Gierusalem celeste. A dunque vani son coloro che sperono che il Messia edifichi tempio visibile. Ancora son vani quegli i quali aspettano che il popolo d'Israel sia da lui congregato, secondo il luogo. Appresso son vani quegli, che stimono nel tempo di Christo tutti i Giudei doversi salvare."

[Hence Rabbi Moses of Egypt in Deuteronomy says that in the sacred scripture, that structure which is spiritual and divine, and which is now called Mount of God, the holy place, is named in many ways: such as the true place of the sanctuary, the sacred way, portico of the Lord, temple of the Lord, house of the Lord, and door of the Lord. This is said by the aforementioned Moses. Rabbi Solomon and Rabbi Abba also considered the construction of the temple as described by Ezekiel to pertain to celestial Jerusalem. Therefore, they are vain who hope that the Messiah will build the visible temple. They are also vain who wait for the people of Israel to be brought together by him to the place. They are vain who think in the time of Christ all the Jews will be saved.]

3. Marsilio Ficino, Della religione christiana (Florence, 1568), 137

"La pietra, che rifiutorono gli edificatori è posta qui in capo di canto. Questo è fatto dal Signore. . . . Gesù rifiutato per disutile da' tristi, fu fatto per divina virtù capo del canto al quale duoi muri si congiungono. Questi sono i gentili \& i giudei convertiti." 
[The stone that the builders have rejected is set here at the head of the corner [cornerstone]. This is the deed of the Lord. . . Jesus, rejected as useless by the evil ones, became through divine virtue the cornerstone to which two walls were joined, that is the Gentiles and the converted Jews.]

4. Marsilio Ficino, Della religione christiana (Florence, 1568), 177

"Parlando di Christo dice. Edificherà tempio al Signore. Aspettano i Giudei che Christo edifichi in terra una grandissima macchina di pietre morte? Ma Gesù per arte divina edificò un tempio celeste di vive pietre dell'anime."

[Speaking of Christ, he says, He will build the temple to the Lord. Are the Jews waiting for Christ to build a great machine of dead stones on earth? But by divine art Jesus built a celestial temple out of the living stones of souls.] 